\title{
Statistical Note
}

\section{Sections 1-4}

\section{Coverage of statistics}

Although a lack of data still limits the scope of the indicators in many countries, the coverage extends, in principle, to the entire national education system (within the national territory) regardless of the ownership or sponsorship of the institutions concerned and regardless of education delivery mechanisms. With one exception described below, all types of students and all age groups are meant to be included: children (including students with special needs), adults, nationals, foreigners, as well as students in open distance learning, in special education programmes or in educational programmes organised by ministries other than the Ministry of Education, provided the main aim of the programme is the educational development of the individual. However, vocational and technical training in the workplace, with the exception of combined school and work-based programmes that are explicitly deemed to be parts of the education system, is not included in the basic education expenditure and enrolment data.

Educational activities classified as "adult" or "non-regular" are covered, provided that the activities involve studies or have a subject matter content similar to "regular" education studies or that the underlying programmes lead to potential qualifications similar to corresponding regular educational programmes. Courses for adults that are primarily for general interest, personal enrichment, leisure or recreation are excluded.

\section{Calculation of international means}

For many indicators an OECD average is presented and for some an OECD total.

OECD average: This is calculated as the unweighted mean of the data values of all OECD countries for which data are available or can be estimated. The OECD average therefore refers to an average of data values at the level of the national systems and can be used to answer the question of how an indicator value for a given country compares with the value for a typical or average country. It does not take into account the absolute size of the education system in each country.

OECD total: This is calculated as a weighted mean of the data values of all OECD countries for which data are available or can be estimated. It reflects the value for a given indicator when the OECD area is considered as a whole. This approach is taken for the purpose of comparing, for example, expenditure charts for individual countries with those of the entire OECD area for which valid data are available, with this area considered as a single entity.

Note that both the OECD average and the OECD total can be significantly affected by missing data. Given the relatively small number of countries, no statistical methods are 
used to compensate for this. In cases where the data value is negligible (code " $n$ ") for the corresponding calculation, the value zero is imputed for the purpose of calculating OECD averages.

\section{Special Section: PISA}

Readers wishing to find out more about the data presented in this section, and the statistical methods used to analyse it, should visit www.pisa.oecd.org or consult PISA 2006, Science Competencies for Tomorrow's World, Volume 1 and Volume 2 (OECD, 2007). 


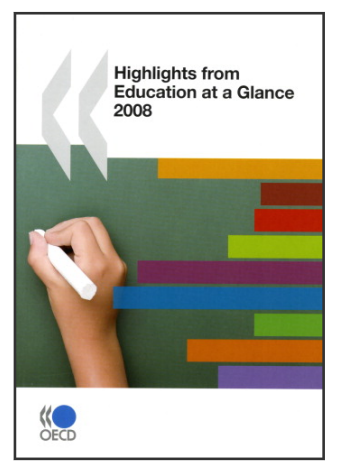

\section{From: \\ Highlights from Education at a Glance 2008}

Access the complete publication at:

https://doi.org/10.1787/9789264040625-en

Please cite this chapter as:

OECD (2009), "Statistical Note", in Highlights from Education at a Glance 2008, OECD Publishing, Paris.

DOI: https://doi.org/10.1787/eag highlights-2008-40-en

This work is published under the responsibility of the Secretary-General of the OECD. The opinions expressed and arguments employed herein do not necessarily reflect the official views of OECD member countries.

This document and any map included herein are without prejudice to the status of or sovereignty over any territory, to the delimitation of international frontiers and boundaries and to the name of any territory, city or area.

You can copy, download or print OECD content for your own use, and you can include excerpts from OECD publications, databases and multimedia products in your own documents, presentations, blogs, websites and teaching materials, provided that suitable acknowledgment of OECD as source and copyright owner is given. All requests for public or commercial use and translation rights should be submitted to rights@oecd.org. Requests for permission to photocopy portions of this material for public or commercial use shall be addressed directly to the Copyright Clearance Center (CCC) at info@copyright.com or the Centre français d'exploitation du droit de copie (CFC) at contact@cfcopies.com. 